\title{
Fiscal Stress: Growth Aspects of Pad, Growth of Capital Expenditure, and Economic Growth
}

\author{
Ilham Sanjaya ${ }^{1}$ Rita Martini ${ }^{1, *}$ Muhammad Fauzan Ahnaf ${ }^{2}$ \\ ${ }^{1}$ Accounting Department, Polytechnic State of Sriwijaya, Palembang 30139, Indonesia \\ ${ }^{2}$ PT. Truckking Lintas Sarana, Jakarta 12950, Indonesia \\ *Corresponding author. Email: ritamartini@polsri.ac.id
}

\begin{abstract}
This study is to determine the effect of growth in local revenue (PAD), growth in capital expenditures and economic growth on fiscal stress. With purposive sampling, it was found that 15 district / city governments in South Sumatra were sampled. Secondary data is in the form of Regional Revenue and Expenditure Budget Realization Reports and data in the form of Domestic and Gross Regional Product data. The test results that the growth in capital expenditures has an effect on fiscal stress, while the growth of PAD and economic growth has no effect on fiscal stress.
\end{abstract}

Keywords: Capital Expenditures, Fiscal Stress, Locally-generated revenue, Economic growth.

\section{PRELIMINARY}

Decentralization will encourage fiscal disparities considering that each region has different readiness both in terms of resource potential and regional financial managerial capacity. Several regions are classified as lucky regions because they have potential sources of revenue, which come from taxes, regional levies, as well as the availability of adequate natural resources that can be used as a source of regional revenue. However, on the other hand, for some regions, autonomy may cause its own problems given the demands to increase regional independence. So that in turn triggers a region to experience fiscal stress ( fiscal stress ).

Efforts to optimize regional potential to increase their fiscal capacity in order to finance regional development are expected to reduce dependence on financing from the central government (Martini et al., 2019). However, the business area to increase the independence of this turned out to trigger the region for experiencing fiscal stress were higher when compared to the period before decentralization (Suyanto, 2017) Often, the revenues received by local governments is not sufficient to fund capital expenditures or development in their regions (Martini et al., 2020). Consequently, high fiscal stress will have an impact on the government's financial performance in regulating and allocating its budget for regional development. In the context of regional development, local governments usually depend on revenues from PAD, Balancing
Funds and other legitimate revenues. The decline in economic activity in an area is of course the cause of the reduced PAD. This decline in economic activity could have been caused by political factors, inappropriate government policies, and uncontrollable factors such as the occurrence of natural disasters, these problems caused PAD revenues to be lower and uncertain. The freedom given to local governments to explore and manage the potential in their regions independently is expected to be able to increase PAD so that they can release regional dependence on the central government. (Kuncoro, 2015) states that PAD should be a measure of the condition of regional financial capacity in managing their households.

The regional expenditure budget always increases every year in line with the economic growth that continues to occur in the area. $\mathrm{S}$ ach implement autonomous region is expected to increase local revenues by digging any new revenue potential for the availability of funds to finance local expenditure remains available (Martini et al., 2019). Economic growth is also a determining factor for the level of social welfare. High economic growth does not necessarily reflect the prosperity of the people, given that economic growth only reflects how the "development cake" is enlarged, but does not yet describe how the "development cake" is distributed evenly in the context of community welfare (Fristanto, 2015). 
The study of fiscal stress at the regional level is becoming increasingly important, especially in the era of regional autonomy, where regions are required to be able to organize their government, provide goods and public services for their citizens. Efforts to increase regional revenues by exploring new revenues must be carried out in order to cover the regional expenditure budgets that are increasing every year (Firstanto, 2015). Apart from the high level of financial dependence on the central government, in recent years there has also been a decline in the value of commodities in the plantation sector, which is the leading sector in South Sumatra. So that it causes the people's economy to decline and has an impact on the acquisition of PAD to be uncertain. This triggered a research to be carried out in the province of South Sumatra.

This research is an effort to improve the results of previous research studies by replacing the operational variable indicators of fiscal stress with the measure introduced by (Arnett, 2011), namely the fund balance. Fund balance (balance of funds $=$ difference between revenue and expenditure) is highly weighted in determining the fiscal stress indicator because it is considered to represent the government's ability to continue operating even in difficult economic conditions. Local governments may have to struggle in dealing with financial problems, but they are still able to survive operations if they have sufficient Funds to absorb the negative impact of these financial problems.

\section{LITERATURE REVIEW}

\subsection{Locally-generated revenue}

Based on Law Number 33 Year 2004 Article 1 concerning Financial Balance between the Central Government and Regional Governments, it is explained that PAD is revenue obtained by a region from sources within its own territory which is collected based on regional regulations in accordance with the prevailing laws and regulations. Meanwhile (Halim, 2014) argues that PAD is one of the components of a source of regional revenue in addition to receiving transfer funds and other legitimate revenues, as a source of funding for government administration in the regions.

\subsection{Gross Regional Domestic Product}

According to (Kuncoro, 2015) GRDP is the amount of added value generated for all business and service areas in one area, applying the total value of the final goods and services produced by all economic units. GRDP calculation according to Soemitro (Septira, Farida, \& Prawira, 2019) is divided into two ways, namely:

\section{a. GRDP at constant prices}

GRDP at constant prices illustrates the added value of goods and services calculated using prices in a certain year as the base year.

\section{b. GRDP at Current Price}

GRDP at current prices illustrates the added value of goods and services calculated using the prevailing prices each year.

\subsection{Capital Expenditures}

According to PP No. 71/2010, capital expenditure is regional government expenditure whose benefits exceed one budget year and will increase regional assets or assets and further add routine expenditures such as maintenance costs in the general administrative expenditure group. Capital expenditures are used to obtain local government fixed assets such as equipment, infrastructure and other fixed assets. How to get capital expenditure by buying through an auction or tender process. Fixed assets owned by local governments as a result of capital expenditures are the main requirement in providing public services. Local governments allocate funds in the form of a capital expenditure budget in the APBD to increase fixed assets.

\subsection{Fiscal Stress}

Fiscal stress is a dynamic condition that raises several aspects and interpretations in defining it (Rakabe, 2013). Based on the existing literature, it shows that fiscal stress is a condition of imbalance between the services desired by the public and what the government provides with the available resources (Septira et al., 2019). Meanwhile, the definition of fiscal stress which is defined (Arnett, 2011) is a condition in which the government is unable to fulfill its financial obligations both in the short and long term and the government is also unable to increase regional revenues or provide public goods and services needed by the government. Public.

To indicate fiscal stress, it can be seen when regional expenditure (in this case capital expenditure) has increased, but if this is not matched by an adequate source of regional income, this can trigger a fiscal stress condition (Shamsub \& Akoto, 2004) in (Septira et al., 2019). Fiscal stress is getting higher due to demands for increased independence aimed at increasing own income to finance various existing expenses. Availability of potential regional resources and regional readiness are important factors for success in the era of autonomy.

\section{FRAMEWORK}

Based on the literature review that has been described, the framework in this study can be described: 


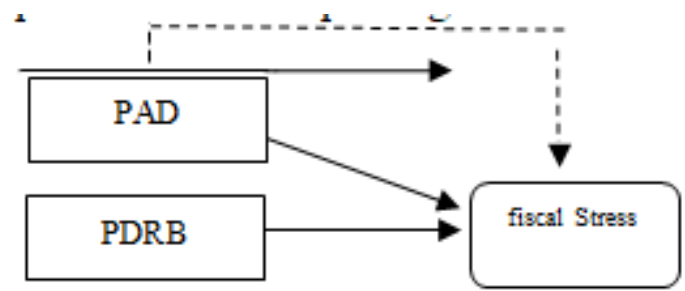

Figure 1. Framework

\subsection{Hypothesis}

H1: The growth of PAD has an effect on Fiscal Stress in districts / cities in South Sumatra Province

H2: GRDP growth affects Fiscal Stress in districts / cities in South Sumatra Province

H3: Capital Expenditure Growth affects Fiscal Stress in districts / cities in South Sumatra Province

H4: Growth of PAD, GRDP, Capital Expenditures simultaneously affect Fiscal Stress in districts / cities in South Sumatra Province

\subsection{Effect of PAD on Fiscal Stress}

growth PAD have an impact on the fiscal stress of an area (Young, 2012). This indicates that PAD growth affects the level of fiscal stress in a region. Any changes in both the increase and decrease in the regional revenue component will cause changes in the level of fiscal stress experienced by the region and the components of the revenue sector in the APBD which have a significant effect on the iscal stress condition is the proportion of regional levies, while the proportion of local taxes is relatively unaffected, even the proportion goes up slightly in the composition of PAD.

\subsection{The Effect of GRDP Growth on Fiscal Stress}

The growth of PAD in the long term will lead to an increase in economic growth in the area so that local governments will take the initiative to explore the potential sources of their region and increase their economic growth. A region can be said to be not prosperous if the area does not experience significant economic growth despite an increase in revenue from PAD. And if the opposite happens, it can indicate the excessive exploitation of PAD against the community without paying attention to the increase in the productivity of the community. Therefore, an increase in PAD must have an impact on the regional economy (Soemitro, 2017). The success of increasing PAD should not only be measured by the amount received but also measured by its role in regulating the community's economy so that it is more developed, so as to improve the welfare of the people in the area. In this case, through an increase in $\mathrm{PAD}$, economic growth as measured by GRDP will have an influence on fiscal stress (Fristanto, 2015).

\subsection{Effect of Capital Expenditure $t$ erhadap Fiscal Stress}

Capital expenditures such as infrastructure in the short term will increase regional expenditure budgets. If it is not balanced with significant revenue, it can cause fiscal stress. Given the fiscal stress here is reflected in the imbalance between the revenue budget and expenditure. Meanwhile, in the long term, the improvement in the quality of infrastructure in a region is expected to increase PAD in the future. This proves that growth in capital spending can affect fiscal stress. This statement is supported by research (Fristanto, 2015) which found that regional spending has a significant effect on fiscal stress. The greater the total regional expenditure, the higher the fiscal stress will be

\section{RESEARCH METHODS}

The data source used in this research is secondary data obtained from the website www.bpk.go.id in the form of the Regional Budget Realization Report (LRA APBD) and data from the website www.bps.go.id

The population of this research is the Budget Realization Report and Gross Regional Domestic Report from 13 Regencies and 4 Cities in South Sumatra Province for 2015 - 2017. The sample data were taken using purposive sampling with the following criteria:

Regencies / Cities in the Province of South Sumatra that have financial reports that have been audited by the Bpk from 2014-2017

Districts / cities in South Sumatra Province that have GRDP growth data from 2015-2017

\subsection{Data analysis technique}

The data used in this research is panel data. Panel data is a combination of time series data and cross section data. Data time series is the data of an object consisting of several periods. Meanwhile, cross-section data is data from several objects at a time. In selecting the right panel data, three approaches are used, namely the Common Effect Model, Fixed Effect Model, and the Random Effect Model. The use of FEM has been chosen twice, namely the Chow Test and Hausman Test. Thus it can be concluded from the three models (CEM, FEM and REM), the best model use is FEM in interpreting the regression of research panel data.

\subsection{Classic assumption test}

A good regression model is one that has a residual value that is normally distributed. To test more accurately, analysis tools and EViews are needed using 
two methods, namely the histogram and the Jarque-Bera test. Multicollinearity is a condition where there is a linear relationship between independent variables. In this study, the method used is by looking at the Tolerance and Variance Inflation Factor (VIF) values. Both of these measures indicate which independent variable is explained by other independent variables. In simple terms, each independent variable becomes the dependent variable and regresses to other independent variables. Each researcher must determine the level of colonierity that can be tolerated (Ghozali, 2017).

Heteroscedasticity is a condition where in the regression model there is an inequality of variants from the residuals from one observation to another. A good regression model does not occur heteroscedasticity. (Priyatno, 2012). There are several methods that can be used to identify the presence or absence of a heteroscedasticity problem. Heteroscedasticity symptoms were tested by the White Test method. This research uses the Lagrange Multiplier Test or often called the Breusch Godfrey Correlation Test. The interpretation of the LM test results can be seen at the Obs * R-Squared probability value with the following assessment bases: Obs * R-Squared probability value> 0.05 , meaning there is no autocorrelation or probability value < 0.05, meaning there is autocorrelation (Winarno, 2015).

\subsection{Multiple Linear Regression Analysis}

Multiple linear regression analysis is an analysis to measure the magnitude of the influence between two or more independent variables on one dependent variable and predict the dependent variable using independent variables (Priyatno, 2012). Multiple linear regression is basically an extension of simple linear regression, namely increasing the number of independent variables. previously only one to two or more independent variables (Sanusi, 2016). Thus, multiple linear regression is expressed in mathematical equations.

\subsection{Determination Coefficient Test (R2)}

The coefficient of determination ( $\mathrm{R} 2$ ) essentially measures how far the model's ability to explain the variation of the dependent variable (Ghozali, 2017) . The coefficient of determination is between zero and one. The value of $\mathrm{R} 2$ small means the ability of independent variables in explaining the variation is very limited dependent variables. A value close to one means that the independent variables provide almost all the information needed to predict variations in the dependent variable (Ghozali, 2017)

\subsection{Statistical test $t$}

The $t$ test or partial regression coefficient test is used to determine whether partially the independent variable has a significant effect on the dependent variable or not. The test uses a significance level of 0.05 and 2 sides
(Priyatno, 2012) . The basis for the decision making is based on the $t$ significance value of each variable in the regression output with EViews 10 with a significance level of 0.05 .

\subsection{Statistical Test $F$}

The F test, namely the regression coefficient test is jointly carried out to test the significance of the effect of several independent variables on the dependent variable. The test uses a significance level of 0.05 (Priyatno, 2012). The F statistical test basically shows whether all the independent or free variables included in the model have a joint influence on the dependent / dependent variable (Ghozali, 2017). The F test can be done by looking at the significance value of $F$ in the output of the regression results using Econometric Views (EViews) with a significance level of $0.05(5 \%)$.

\section{RESULTS AND DISCUSSION}

\subsection{Research result}

The result of the normality test obtained a JarqueBera value of 3.795548 and a probability ( $\mathrm{p}$-value) value of 0.149902 . The probability ( $p$-value) value is more than $\alpha(0.149902>0.05)$, then H0 is accepted. So it can be concluded that the data are normally distributed. The result of the multicollinearity test shows that the VIF value of each independent variable in the Centered VIF column has a value below the number 10 so that it can be said that there is no multicollinearity in each of these independent variables. Heteroscedasticity is a condition where in the regression model there is an inequality of variants from the residuals from one observation to another. $\mathrm{H}$ acyl heteroscedasticity test values obtained Obs * R- squared value of 5.539899 and value Probability Chi-S quare (9) of 0.7849 . The pvalue (probability Chi- Square) is more than $\alpha(0.7849>$ $0.05)$, then $\mathrm{H} 0$ is accepted. So it can be concluded that the data does not occur heteroscedasticity. Autocorrelation is a condition where in the regression model there is a correlation between the residuals in period $\mathrm{t}$ and the residuals in the previous period $(\mathrm{t}-1)$. The result of the autocorrelation test shows that the Obs * R-squared value is 1.335313 and the Chi-Square Probability value (3) is 0.5129 . The p-value (probability Chi-Square) is more than $\alpha(0.5129>0.05)$, then $\mathrm{H} 0$ is accepted. So it can be concluded that the data does not occur autocorrelation.

Based on the estimation results for Multiple Linear Regression Analysis using the Fixed Effect Model (FEM) approach, the equation results are:

Fiscal Stress $=-1333.070+0.105903$ Growth in PAD + 17.27545 Growth in GRDP - 1.70521 Growth in Capital Spending + e

Based on table 1, the results of the coefficient of determination show that the R2 value is 0.96 , which 
means that the percentage of contribution to the influence of PAD growth, GRDP, capital expenditure on Fiscal Stress is $96 \%$, while the remaining $4 \%$ is influenced by other variables not included in this model.

Table 1. Effects Specification

\begin{tabular}{|l|c|}
\hline \multicolumn{2}{|c|}{ Effects Specification } \\
\hline R-squared & 0.978262 \\
\hline Adjusted R-squared & 0.964576 \\
\hline S.E. of regression & 89.19330 \\
\hline F-statistic & 71.47552 \\
\hline Prob(F-statistic) & 0.000000 \\
\hline
\end{tabular}

source: Output Eviews 10 (2019)

Based on the significance, if the significance $<0.05$ then $\mathrm{H} 1$ is accepted, and if the significance $>0.05$ then $\mathrm{H} 1$ is rejected. Because the significance of the $\mathrm{t}$ test is more than $0.05(0.7224>0.05), \mathrm{H} 1$ is rejected. it can be concluded variables Growth in revenue is partially not influence significantly to fiscal stress. The $\mathrm{t}$ value $<\mathrm{t}$ table $(0.912612<2.833)$ and the significance of the $t$ test is more than $0.05(0.3695>0.05)$ then $\mathrm{H} 2$ is rejected. Because the value of $\mathrm{t}$ count $<\mathrm{t}$ table $(-2.941912<-$ 2.833) the significance of the $t$ test is less than 0.05 $(0.0066<0.05)$ then $\mathrm{H} 3$ is accepted. So it can be concluded that the variable capital expenditure growth partially has a significant negative effect on fiscal stress

Table 2. the calculation results

\begin{tabular}{|c|r|r|r|r|}
\hline & Coefficient & Std. Error & t-Statistic & Prob. \\
\hline C & -1333.070 & 94.32756 & -14.13235 & 0.0000 \\
\hline $\mathrm{X} 1$ & 0.105903 & 0.294954 & 0.359050 & 0.7224 \\
\hline $\mathrm{X} 2$ & 17.27545 & 18.92966 & 0.912612 & 0.3695 \\
\hline $\mathrm{X} 3$ & -1.505721 & 0.511817 & -2.941912 & 0.0066 \\
\hline
\end{tabular}

source: Output Eviews 10 (2019)

The result of the $\mathrm{F}$ test can be seen that the $\mathrm{F}$ count is 71.47552 to determine the F table, it can be seen in the statistical table at a significance level of 0.05 with df 1 (number of variables-1) $=4$, and df 2 (nk-1) or $45-3-1=41$ ( $\mathrm{n}$ is the number of data and $\mathrm{k}$ is the number of independent variables). The results obtained for the F table are 2, 833 (see statistical table). Because $\mathrm{F}$ count $>\mathrm{F}$ table $(71.47552>2.833)$ and the significance on the $\mathrm{F}$ test is less than $0.05(0.000000$ $<0.05$ ) then $\mathrm{H} 4$ is accepted. So it can be obtained F count equal to 71.41094 with significant value 0.000000 , it can be concluded variables growth PAD, the GDP, and $b$ elanja $m$ orking together have an influence on Fiscal Stress

\subsection{Discussion}

PAD growth that continues to increase can basically reduce fiscal stress conditions, because fiscal stress itself indicates that the region is still unable to optimize the sources of regional income. In fact, the increase in PAD in districts / cities in South Sumatra has not been able to finance its expenditures. In 2015-2017 the average fiscal stress level of districts / cities in South Sumatra fluctuates and can be said to tend to decline, this is inversely proportional to the growth of PAD which every year has increased, so that it can be the cause of how PAD growth does not affect fiscal stress .

The ideal condition in the economy of a region is where the GRDP always increases from year to year so that from the GRDP, local governments can collect revenues in their regions which also increase. Nonetheless, based on the results of descriptive analysis, the average GRDP growth of districts / cities in South Sumatra in 2015-2017 shows a fluctuating trend. When compared with the level of fiscal stress, GDP growth has no correlation, where the fiscal stress in districts / cities in South Sumatra tends to increase

Fiscal stress (Arnett, 2011) is as a government's inability to meet short-term financial liabilities and long-term as they arise and may be accompanied by an inability to increase revenue, resulting in non-fulfillment of the supply of goods and services to the public. If the income is lower than the expenditure, then the area is indicated in a fiscal stress condition and vice versa if the income is greater than the expenditure, the area is not in a fiscal stress condition.

The growth of capital expenditure has an effect on fiscal stress (Fristanto, 2015). If a region increases its expenditure but is not balanced with a significant increase in $\mathrm{PAD}$, then that region can experience fiscal stress and dependence on transfer funds from the central government (Martini et al., 2020). However, (Muda, 2012) and (Septira et al., 2019) state that capital expenditure growth has no effect on fiscal stress.

The increase in fiscal stress is caused by declining economic growth or recession, industrial decline resulting in reduced tax returns and the role of bureaucratic inefficiency, corruption, high salaries for employees and high spending (Shamsub \& Akoto, 2004). However, fiscal stress does not always have a negative impact because when local governments experience high fiscal stress there is a tendency for the government to explore PAD more closely so that it can finance its expenditure.

The relatively good potential of domestic products will increase the rate of economic growth, in other words the direction of economic development is to ensure that people's income will increase and be evenly distributed. The increase in community income will 
affect the community in exploring potential sources of potential in the region, which will have an impact on increasing regional revenue, and reducing the occurrence of the fiscal stress phenomenon, because regions will be able to finance regional development through the regional income they have. Growth PAD, the GDP and capital expenditure simultaneously significant effect on fiscal stress (Firstanto, 2015), (Septira et al., 2019), (Young, 2012) and (Martini et al., 2019). However, (Gunara, 2017) suggests that fiscal stress is not simultaneously affected by the growth of PAD, GRDP, and capital expenditure.

\section{CONCLUSION}

Growth PAD does not affect the fiscal stress. This is because the PAD owned by district / city governments in the province is still worth a very large deficit when compared to the total expenditure allocation, so PAD has not become the main source of financing for expenditure allocations. Economic growth projected with GRDP has no effect on fiscal stress. This is due to the fluctuations in GDP growth that goes up and down so that it is proven that it cannot affect fiscal stress conditions. Growth capital expenditures affect negatively to fiscal stress, indicating any increase in capital expenditures will directly impact the level of fiscal stress in the area. The larger the allocation of budgeted expenditure, the possibility of the area experiencing fiscal stress was also higher. Ideally, capital expenditure each year has increased because this expenditure allocation is used for public services and productive matters and will affect the people's economy, but if the amount of expenditure allocation is not balanced with adequate PAD, it will have an impact on fiscal stress.

Growth of PAD, GRDP and Capital Expenditures simultaneously influence fiscal stress. The efforts of local governments to increase PAD and GRDP and then manage the appropriate allocation of capital expenditures can affect the level of fiscal stress.

The regional government is expected to be able to manage the allocation of expenditures properly, thereby encouraging the acceleration of the community's economy and improving public services. The regional government is also expected to be able to optimize efforts to increase the resources of PAD by exploring the potential sources of wealth owned by the region, so that it can meet its expenditure and can reduce dependence on transfer funds disbursed by the central government.

Further researchers are advised to use other independent variables that are thought to have an influence on fiscal stress, for example the DAU to measure fiscal stress in local governments. If the amount of DAU grows, it can be said that the capacity of regional financing for mandatory expenditure is decreasing, this may indicate that the local government is experiencing fiscal stress. Researchers can also increase the timeframe and object of research to increase the accuracy of the quality of the research results.

\section{REFERENCES}

[1] Adriana, M., Muthia, Y. B., \& Indrawati, N. (2017). Variabel Yang Mempengaruhi Fiscal Stress Di Kabupaten/Kota Se-Provinsi Riau. Jurnal Ekonomi, 25, 45-60.

[2] Ahmad, H. (2015). Pengaruh Kinerja Keuangan, Fiscal Stress, dan Kepadatan Penduduk terhadap Alokasi Belanja Modal di Nusa Tenggara Barat. 152-166.

[3] Ajija, S. R., Sari, D. W., Setianto, R. H., \& Primanti, M. R. (2011). Cara Cerdas Menguasai Eviews. Jakarta: Salemba Empat.

[4] Arnett, S. (2011). Fiscal Stress in the U. S. States: an Analysis of Measures and Responses Copyright 2011 By Sarah Arnett Fiscal Stress in the U. S. Georgia Institute of Technology.

[5] Brodjonegoro, B. P., \& Dartanto, T. (2013). Dampak Desentralisasi Fiskal Terhadap Perekonomian dan Kesenjangan Daerah: Analisa Model Makro Ekonometrik Simultan. Indonesian Journal of Economic and Development, 4.

[6] Fristanto, R. (2015). Analisis Pengaruh Pertumbuhan PAD, PDRB, dan Belanja Modal Terhadap Fiscal Stress Pada Kabupaten dan Kota di Provinsi Jawa Tengah. Universitas Diponegoro.

[7] Ghozali, I. (2017). Aplikasi Analisis Multivariate Dengan Program IBM SPSS 25 (9th ed.). Semarang: Badan Penerbit Universitas Diponegoro.

[8] Gunara, E. (2017). Pengaruh Pertumbuhan Pendapatan Asli Daerah, Pertumbuhan Ekonomi Dan Belanja Modal Terhadap Fiscal Stress Di Provinsi Kalimantan Tengah. Univerisity of Gajah Mada.

[9] Halim, A. (2001). Anggaran daerah dan "fiscal stress" (sebuah studi kasus pada Anggaran daerah provinsi di Indonesia. Jurnal Ekonomi dan Bisnis Indonesia. Ekonomi Dan Bisnis Indonesia, 16(4), 346-357.

[10] Halim, A. (2014). Manajemen Keuangan Sektor Publik. jakarta: Salemba Empat.

[11] Halim, A., \& Kusufi, M. S. (2014). Akuntansi Sektor Publik. jakarta: Salemba Empat. 
[12] Khakim, L., Hermawan, I., Solechan, A., \& PS, V. T. (2017). Potensi Fiskal terhadap Pertumbuhan Ekonomi Dan Kesejahteraan Masyarakat. Jurnal Ekonomi Pembangunan: Kajian Masalah Ekonomi Dan Pembangunan,

[13] Kuncoro, M. (2015). Mudah Memahami \& Menganalisis Indikator Ekonomi. Yogyakarta: UPP STIM YKPN.

[14] Mahmudi. (2016). Analisis Laporan Keuangan Pemerintah Daerah. Yogyakarta: UPP STIM YKPN.

[15] Martini, Rita, Agustin, Resy, \& Sari, K. R. 2020. Accrual Discretion Policy on Excess/Less Budget Financing at the Provincial Level. TEST Engineering \& Management, 82, 9925-9935.

[16] Martini, Rita, Sari, K. R., Somadi, T., \& Karman, I. W. 2019. Financial Independence of the South Sumatra Regional Government. Proceedings of the International Conference on Applied Science and Technology 2019 - Social Sciences Track (iCASTSS 2019). Volume 354, pp. 360-364. Denpasar: Atlantis Press. https://doi.org/10.2991/icastss-19.2019.75

[17] Martini, Rita, Zulkifli, Hartati, Sukmini, \& Widyastuti, Endah. 2019. Dimension of Village Expenditure in Development Sector. Proceedings of the 3rd Forum in research, Science, and Thecnology (FIRST 2019). Advances in Social Science, Education and Humanities Research, Volume 431, pp. 6-9. Atlantis Press. https://doi.org/10.2991/assehr.k.200407.002.

[18] Muda, I. (2012). Variabel yang Mempengaruhi Fiscal Stress pada Kabupaten/Kota Sumatera Utara. Jurnal Keuangan \& Bisnis, 4 No.1.

[19] Priyatno, D. (2012). Cara Kilat Belajar Analisis Data dengan SPSS 20. jakarta: Andi Publisher.

[20] Pulungan, F. S., Daulay, M., \& Siregar, H. S. (2017). Faktor-Faktor yang Mempengaruhi
Pertumbuhan Ekonomi dengan Belanja Daerah Sebagai Variabel Moderating pada kabupaten/kota Di Provinsi Sumatera Utara. Jurnal Ilmiah"INTEGRITAS", 3(2).

[21] Rakabe, E. (2013). The State of Fiscal Stress in South Africa' $s$ Provinces: Improving fiscal performance List of Figures.

[22] Sanusi, A. (2016). Metodologi Penelitian Bisnis (6th ed.). Jakarta: Salemba Empat.

[23] Sarwono, J. (2016). Prosedur-prosedur Analisis Populer Aplikasi Riset Skripsi dan Tesis dengan EViews (1st ed.). Yogyakarta: Gava Media.

[24] Septira, F., Farida, I., \& Prawira, A. (2019). Analisis Faktor-Faktor Yang Mempengaruhi Fiscal Stress. Pendidikan Akuntansi Dan Keuangan, 7(1), 57-64.

[25] Shamsub, H., \& Akoto, J. B. (2004). State and Local Fiscal Structures and Fiscal Stress. Journal of Public Budgeting, Accounting \& Financial Management, 16(1), 40-61.

[26] Soemitro, S. (2017). Analisis Ekonomi Jawa Barat. Bandung: Unpad Press.

[27] Suyanto, S. (2017). Kajian Ketimpangan Fiskal (Fiscal Imbalance) Dan Kebijakan Desentralisasi Fiskal Pada Daerah Otonom. Develop, 1(1), 1-21. https://doi.org/10.25139/dev.v1i1.70

[28] Syaiful. (2008). Pengertian dan Perlakukan Akuntansi Belanja Barang dan Belanja Modal dalam Kaidah Akuntansi pemerintahan. Jakarta.

[29] West, J. P. (2014). Municipal Government Strategies for Controlling Personnel Costs During the Fiscal Storm. (March 2011). https://doi.org/10.1108/JPBAFM-23-03-2011B005

[30] Winarno, W. Wahyu. (2015). Analisis Ekonometrika dan Statistika dengan EViews (4th ed.). Yogyakarta: UPP STIM YKPN. 